\title{
Observations and implications of liquid-liquid phase separation at high relative humidities in secondary organic material produced by $\alpha$-pinene ozonolysis without inorganic salts
}

\author{
Lindsay Renbaum-Wolff ${ }^{1, a,{ }^{*}, \text { Mijung Song }}{ }^{1, b, *}$, Claudia Marcolli ${ }^{2,3}$, Yue Zhang ${ }^{4, a}$, Pengfei F. Liu ${ }^{4}$, \\ James W. Grayson ${ }^{1}$, Franz M. Geiger ${ }^{5}$, Scot T. Martin ${ }^{4,6}$, and Allan K. Bertram ${ }^{1}$ \\ ${ }^{1}$ Department of Chemistry, University of British Columbia, Vancouver, BC, V6T 1Z1, Canada \\ ${ }^{2}$ Marcolli Chemistry and Physics Consulting GmbH, Zurich, Switzerland \\ ${ }^{3}$ Institute for Atmospheric and Climate Science, ETH Zurich, Zurich, Switzerland \\ ${ }^{4}$ School of Engineering and Applied Sciences, Harvard University, Cambridge, MA 02138, USA \\ ${ }^{5}$ Department of Chemistry, Northwestern University, Evanston, IL 60208, USA \\ ${ }^{6}$ Department of Earth and Planetary Sciences, Harvard University, Cambridge, MA 02138, USA \\ ${ }^{a}$ now at: Aerodyne Research, Inc, Billerica, MA 01821 and Boston College, Chestnut Hill, MA 02467, USA \\ ${ }^{b}$ now at: Department of Earth and Environmental Sciences, Chonbuk National University, Jeollabuk-do, Republic of Korea \\ *These authors contributed equally to this work.
}

Correspondence to: Allan K. Bertram (bertram@chem.ubc.ca) and Scot T. Martin (scot_martin@ harvard.edu)

Received: 18 October 2015 - Published in Atmos. Chem. Phys. Discuss.: 26 November 2015

Revised: 14 April 2016 - Accepted: 6 May 2016 - Published: 1 July 2016

\begin{abstract}
Particles consisting of secondary organic material (SOM) are abundant in the atmosphere. To predict the role of these particles in climate, visibility and atmospheric chemistry, information on particle phase state (i.e., single liquid, two liquids and solid) is needed. This paper focuses on the phase state of SOM particles free of inorganic salts produced by the ozonolysis of $\alpha$-pinene. Phase transitions were investigated in the laboratory using optical microscopy and theoretically using a thermodynamic model at $290 \mathrm{~K}$ and for relative humidities ranging from $<0.5$ to $100 \%$. In the laboratory studies, a single phase was observed from 0 to $95 \%$ relative humidity (RH) while two liquid phases were observed above $95 \%$ RH. For increasing RH, the mechanism of liquid-liquid phase separation (LLPS) was spinodal decomposition. The $\mathrm{RH}$ range over which two liquid phases were observed did not depend on the direction of RH change. In the modeling studies, the SOM took up very little water and was a single organic-rich phase at low RH values. At high $\mathrm{RH}$, the SOM underwent LLPS to form an organic-rich phase and a water-rich phase, consistent with the laboratory studies. The presence of LLPS at high RH values can have consequences for the cloud condensation nuclei (CCN) activity of SOM
\end{abstract}

particles. In the simulated Köhler curves for SOM particles, two local maxima were observed. Depending on the composition of the SOM, the first or second maximum can determine the critical supersaturation for activation. Recently researchers have observed inconsistencies between measured $\mathrm{CCN}$ properties of SOM particles and hygroscopic growth measured below water saturation (i.e., hygroscopic parameters measured below water saturation were inconsistent with hygroscopic parameters measured above water saturation). The work presented here illustrates that such inconsistencies are expected for systems with LLPS when the water uptake at subsaturated conditions represents the hygroscopicity of an organic-rich phase while the barrier for $\mathrm{CCN}$ activation can be determined by the second maximum in the Köhler curve when the particles are water rich.

\section{Introduction}

Particles consisting of secondary organic material (SOM) can account for $20-80 \%$ of the total submicron organic mass concentrations in the atmosphere (Zhang et al., 2007; 
Jimenez et al., 2009). SOM in the particle phase consists of the low volatility fraction of the oxidized products of biogenic or anthropogenic volatile organic compounds (Hallquist et al., 2009). To predict the role of SOM particles for climate, visibility and atmospheric chemistry, information on the phase state within individual SOM particles (e.g., one liquid, two liquids and one solid) is needed. Particle phase state influences the properties of particles such as cloud condensation nuclei $(\mathrm{CCN})$ properties, optical properties and interactions with reactive and non-reactive gas-phase species (Martin et al., 2000; Raymond and Pandis, 2002; Bilde and Svenningsson, 2004; Zuend et al., 2010; Kuwata and Martin, 2012).

A possible phase transition of SOM particles during relative humidity (RH) cycling is liquid-liquid phase separation (LLPS) (Pankow et al., 2003; Petters et al., 2006). LLPS has been observed in the laboratory when SOM produced by $\alpha$-pinene ozonolysis was combined with ammonium sulfate and for other organic systems when mixed with inorganic salts when the average organic oxygen-to-carbon elemental ratios $(\mathrm{O}: \mathrm{C}$ ) were less than approximately 0.8 (Krieger et al., 2012; You et al., 2014). The presence of the ammonium sulfate causes salting-out of the organic material and the formation of two liquid phases. However, we are not aware of previous laboratory studies focusing on LLPS in SOM in the absence of inorganic salts.

This paper focuses on phase transitions of SOM produced by $\alpha$-pinene ozonolysis free of inorganic salts. $\alpha$-pinene was chosen for the precursor gas for SOM because it is an important contributor to organic particle mass in the atmosphere, especially in regions such as boreal forests (Cavalli et al., 2006). Phase transitions were investigated both in the laboratory and with a thermodynamic model over the range of $<0.5 \%$ to $100 \% \mathrm{RH}$.

\section{Methods}

\subsection{Laboratory studies}

\subsubsection{Production and collection of secondary organic material}

Particles of secondary organic material were produced by $\alpha$ pinene ozonolysis in a flow tube reactor by the methods described in Shrestha et al. (2013). To remove excess reactants, the aerosol in the outflow from flow tube reactor continued through a diffusion dryer charged with ozone destruction catalyst (Ozone Solutions, model ODS-2) and a carbon filter denuder (Sunset Laboratory). Particle mass concentrations in the flow tube reactor ranged from 75 to $11000 \mu \mathrm{g} \mathrm{m}^{-3}$ (Table 1).

At the outlet of the flow tube reactor, particles were collected using one of two different methods. In the first method, after charging in a bipolar charger (TSI, model 3077), a portion of the flow $(1.5 \mathrm{slpm})$ was sampled into a Nanometer Aerosol Sampler (TSI, model 3089). The particles were collected by electrostatic precipitation $(-10 \mathrm{kV}$ sampler potential) onto a siliconized glass slide (Hampton Research, Canada). This method of collection resulted in submicron particles distributed evenly over the glass slide (Liu et al., 2013). In the second method, a portion $(1.5 \mathrm{slpm})$ of the aerosol flow exiting the flow reactor was sampled into a single stage impactor (Prenni et al., 2009; Pöschl et al., 2010). The collection substrate was a glass slide coated with trichloro $(1 \mathrm{H}, 1 \mathrm{H}, 2 \mathrm{H}, 2 \mathrm{H}$-perfluorooctyl)silane (SigmaAldrich, $97 \%$ purity). The coating procedure, which was described in Knopf (2003), produced a hydrophobic surface. The size of the particles after coagulation on the glass slides ranged from 10 to $80 \mu \mathrm{m}$ in diameter. Table 1 lists samples collected by method 1 or method 2 .

For the optical microscope experiments (see Sect. 2.1.2), supermicron particles are needed, and in the case of method 1 the collected submicron particles were exposed to water supersaturation (SS) conditions to grow and coagulate the particles (Song et al., 2015). Specifically, the slides containing the submicron particles were mounted to a temperature and RH-controlled flow cell, which was coupled to a reflectance microscope, as described previously (Koop et al., 2000; Parson et al., 2004; Pant et al., 2006). The RH in the flow cell was initially set to $>100 \%$ by decreasing the cell temperature to below the dew point temperature. At the initial RH $(>100 \%)$ water condensed on the slides forming large (150$300 \mu \mathrm{m})$ droplets by growth and coagulation. The RH was then ramped back to $\sim 98 \%$ by warming the cell back to room temperature, resulting in water evaporating from the droplets. This process of coagulation followed by evaporation resulted in SOM particles with lateral dimensions of 5$30 \mu \mathrm{m}$.

This hygroscopic cycling of method 1 did introduce the possibility for aqueous phase reactions to occur (e.g., simulating cloud water reactions) that might not be present under subsaturated conditions (e.g., aerosol water only). Furthermore, during the RH cycle some of the secondary organic material may have evaporated from the particles. However, the similarities in the results for two collection methods (see Table 1) suggest that neither of these possible processes, if present, changed the chemical composition enough to influence LLPS. Also, prior to collection with both methods, excess gas-phase components were removed with a carbon filter. During this process, some of the more volatile material in the SOM may have evaporated. If some evaporation of higher volatility species occurred, the SOM would likely be more similar to the chemical composition of SOM particles in the atmosphere, which are formed at lower particle mass concentrations compared to particles in the current laboratory experiments. 
Table 1. Summary of experimental conditions for the production and collection of $\alpha$-pinene-derived SOM. SOM samples 2, 3, 4, 5, 7 and 8 were collected on hydrophobic substrates using a single stage impactor. SOM samples 1, 6 and 9 were collected on hydrophobic substrates using an electrostatic precipitator. The separation relative humidity (SRH) from one to two phases is listed for each SOM. The standard deviation (stdev) is derived from several cycles of RH for different deposited particles. In cases for which the SRH was only determined for one humidity cycle (SOM samples 3-5), the error represents the maximum error reported for the other SOM samples. SOM particle mass concentration refers to the concentration of organic particles suspended in the gas phase at the time of SOM production.

\begin{tabular}{llllllll}
\hline $\begin{array}{l}\text { SOM } \\
\text { sample }\end{array}$ & $\begin{array}{l}\alpha \text {-pinene } \\
(\mathrm{ppm})\end{array}$ & $\begin{array}{l}\mathrm{O}_{3} \\
(\mathrm{ppm})\end{array}$ & $\begin{array}{l}\text { SOM particle mass } \\
\left(\mu \mathrm{g} \mathrm{m}^{-3}\right) \text { concentration }\end{array}$ & $\begin{array}{l}\text { Collection time } \\
(\mathrm{min})\end{array}$ & $\begin{array}{l}\text { SRH }(\%) \pm \mathrm{SD} \text { with } \\
\text { decreasing RH }\end{array}$ & $\begin{array}{l}\text { SRH }(\%) \pm \text { SD with } \\
\text { increasing RH }\end{array}$ & $\begin{array}{l}\text { Collection } \\
\text { method }\end{array}$ \\
\hline 1 & 0.20 & 16 & 75 & 3120 & $96.2 \pm 0.41$ & $96.4 \pm 0.03$ & 1 \\
2 & 0.35 & 10 & 85 & 5580 & $95.8 \pm 0.18$ & $95.9 \pm 0.04$ & 2 \\
3 & 0.35 & 10 & 95 & 5733 & $95.1 \pm 0.41$ & $95.2 \pm 0.41$ & 2 \\
4 & 0.35 & 10 & 110 & 2160 & $94.7 \pm 0.13$ & $95.0 \pm 0.41$ & 2 \\
5 & 0.80 & 10 & 320 & 1590 & $95.2 \pm 0.41$ & $96.3 \pm 0.41$ & 1 \\
6 & 1.00 & 20 & 1500 & 1440 & $96.2 \pm 0.39$ & $96.1 \pm 0.08$ & 2 \\
7 & 5.00 & 10 & 2900 & 1520 & $97.3 \pm 0.08$ & $96.7 \pm 0.39$ & $96.5 \pm 0.21$ \\
8 & 5.00 & 10 & 2900 & 1472 & $95.8 \pm 1.05$ & $96.5 \pm 0.28$ \\
\hline
\end{tabular}

\subsubsection{Method of determining SOM phase(s)}

Hydrophobic substrates containing the supermicron particles were located within a flow cell with temperature and $\mathrm{RH}$ control and coupled to a reflectance microscope (Zeiss, AxioTech, $50 \times$ objective) for observation (Koop et al., 2000; Parson et al., 2004; Pant et al., 2006). During experiments, the RH was changed by adjusting the moisture content of the gas flow. The RH was measured with a chilled-mirror hygrometer (General Eastern, model 1311DR), which was calibrated using the deliquescence $\mathrm{RH}$ of pure ammonium sulfate particles. During typical experiments, the RH was first set to $\sim 100 \%$, and then the RH was ramped down at a rate of $0.1-0.3 \% \mathrm{RH} \min ^{-1}$ and images were collected every 5-20 s. After the $\mathrm{RH}$ reached $\leq 0.5 \% \mathrm{RH}$, it was ramped up again at the same rate to $\sim 100 \%$. During the experiments, temperature was constant at $290 \pm 1 \mathrm{~K}$. From images recorded while changing the $\mathrm{RH}$, the number of phases present in the SOM was determined.

During the experiments used to determine SOM phase state the concentration of organic vapors in the flow cell was not controlled. Hence, some of the more volatile material in the SOM may have evaporated during these experiments. However, no visible change in the particle volume occurred during these experiments, suggesting evaporative loss was minimal. The SOM particle mass concentrations used when generating the SOM were similar to those used in Grayson et al. (2016), and the sample preparation methods were identical to those used in Grayson et al. (2016), who showed no visible volume change of the droplets over time periods of greater than $44 \mathrm{~h}$. It is possible that condensed-phase reactions may have occurred that lowered the vapor pressure of the SOM.

\subsection{Thermodynamic modeling studies}

Liquid-liquid equilibria and water uptake were calculated with the methods developed by Zuend et al. (2008, 2010, 2011) and Zuend and Seinfeld (2012, 2013). To calculate activity coefficients of the organic species as a function of the solution composition, the thermodynamic groupcontribution model AIOMFAC (Aerosol Inorganic-Organic Mixtures Functional groups Activity Coefficients) developed by Zuend et al. $(2008,2010,2011)$ was utilized. To determine whether two liquid phases or a single liquid phase was the thermodynamic stable state, the Gibbs free energies of a two-liquid phase state and a one-liquid phase state were calculated (Zuend et al., 2010). If the two-liquid phase state had a lower Gibbs free energy compared to the one liquid phase state, then LLPS was predicted.

To represent SOM from the ozonolysis of $\alpha$-pinene, the oxidation products listed in Table 2 were used. These oxidation products were based on the calculations performed by Zuend and Seinfeld (2012), who used the Master Chemical Mechanism (Jenkin et al., 1997; Saunders et al., 2003) in combination with EVAPORATION (Compernolle et al., 2011) to establish a representative condensed-phase composition of oxidation products from the ozonolysis of $\alpha$-pinene. Three different mixtures of the oxidation products were used in the current study (see Tables 2 and 3). The mixtures SOMhigh and SOM-low are based on calculations by Zuend and Seinfeld (2012) carried out at $60 \%$ RH yielding particle mass concentrations of 21.86 and $0.81 \mu^{-3} \mathrm{~m}^{-3}$, respectively (see Fig. 4 from Zuend and Seinfeld, 2012). The SOM-ox mixture used the same oxidation products as SOM-high and SOMlow mixtures, but the share of the more oxidized products was increased. Water uptake and CCN activation for these mixtures were simulated assuming that all oxidation products remained in the condensed phase without further gas-to- 
Table 2. Molecular weights $\left(\mathrm{M}_{w}\right), \mathrm{O}: \mathrm{C}$ elemental ratios and mole fractions of the $\alpha$-pinene ozonolysis products from Zuend and Seinfeld (2012) used in the thermodynamic modeling study. Three different scenarios were investigated: high SOM concentrations (SOM-high), low SOM concentration (SOM-low) and with higher shares of the more oxidized products (SOM-ox).

\begin{tabular}{llllll}
\hline Name & $M_{\mathrm{w}}\left(\mathrm{g} \mathrm{mol}^{-1}\right)$ & O:C & \multicolumn{3}{c}{ Mole fraction in mixture } \\
& & & SOM-high & SOM-low & SOM-ox \\
\hline C107OOH & 200.231 & 0.4 & 0.039 & 0.013 & 0.009 \\
Pinonic acid & 184.232 & 0.3 & 0.016 & 0.000 & 0.000 \\
C97OOH & 188.221 & 0.444 & 0.310 & 0.042 & 0.030 \\
C108OOH & 216.231 & 0.5 & 0.050 & 0.012 & 0.009 \\
ALDOL_dimer & 368.421 & 0.368 & 0.029 & 0.079 & 0.056 \\
Pinic acid & 186.205 & 0.444 & 0.167 & 0.156 & 0.110 \\
C921OOH & 204.220 & 0.556 & 0.138 & 0.271 & 0.192 \\
C109OOH & 200.231 & 0.4 & 0.005 & 0.000 & 0.000 \\
C812OOH & 190.194 & 0.625 & 0.128 & 0.277 & 0.245 \\
ESTER_dimer & 368.421 & 0.368 & 0.005 & 0.021 & 0.015 \\
C811OH & 158.094 & 0.375 & 0.012 & 0.000 & 0.000 \\
Hopinonic acid & 200.232 & 0.4 & 0.058 & 0.026 & 0.019 \\
C813OOH & 206.193 & 0.75 & 0.042 & 0.102 & 0.316 \\
\hline
\end{tabular}

particle partitioning to isolate the effect of LLPS. The average $\mathrm{O}: \mathrm{C}$ ratios used in the thermodynamic modeling studies are similar to those measured in environmental chambers (e.g., see Chhabra et al. (2011) and references therein).

The oxidation products and mole fractions used in the thermodynamic modeling studies were used to (1) improve our understanding of the phase state of multicomponent organic mixtures such as those generated during SOM formation from $\alpha$-pinene ozonolysis and (2) to explore the possible implications of liquid-liquid phase separation in multicomponent organic mixtures such as SOM. However, the oxidation products and their mole fractions were not intended to reproduce the laboratory conditions used here or atmospheric SOM.

In addition to detecting the presence of LLPS, the thermodynamic model was used to predict the hygroscopic growth factor (HGF), CCN activation and the hygroscopicity parameter $(\kappa)$, from calculations of hygroscopic growth $\left(\kappa_{\mathrm{HGF}}\right)$ and calculations of CCN activation $\left(\kappa_{\mathrm{CCN}}\right)$ (see Table 3 ). The hygroscopic growth factor was calculated with the following Eq. (1):

$\mathrm{HGF}(\mathrm{RH})=\frac{D(\mathrm{RH})}{D_{0}}$,

where $D(\mathrm{RH})$ and $D_{0}$ represent the wet and the dry diameters of the particles, respectively. The dry diameter $D_{0}$ was calculated at $0 \% \mathrm{RH}$. The following equation was used to calculate the $\kappa_{\mathrm{HGF}}$ (Petters and Kreidenweis, 2007; Pajunoja et al., 2015):

$\kappa_{\mathrm{HGF}}=1-\mathrm{HGF}^{3}+\frac{\mathrm{HGF}^{3}-1}{\frac{\mathrm{RH}}{100 \%}} e^{\left(\frac{4 \sigma M_{\mathrm{w}}}{R T \rho_{\mathrm{w}} D_{0} \mathrm{HGF}}\right)}$,

where $\sigma$ is surface tension at the particle-air interface, $M_{w}$ is the molecular weight of water $\left(18 \mathrm{~g} \mathrm{~mol}^{-1}\right), R$ is the univer- sal gas constant, $T$ is temperature $(298 \mathrm{~K})$ and $\rho_{\mathrm{w}}$ is the density of water $\left(1 \mathrm{~g} \mathrm{~cm}^{-3}\right)$. The following equation was used to calculate $\kappa_{\mathrm{CCN}}$ (Petters and Kreidenweis, 2007; Pajunoja et al., 2015):

$\kappa_{\mathrm{CCN}}=\frac{4 A_{\text {Kelvin }}^{3}}{27 d_{\mathrm{c}}^{3} \ln ^{2} S_{\mathrm{c}}}$,

where

$A_{\text {Kelvin }}=\frac{4 \sigma M_{\mathrm{w}}}{R T \rho_{\mathrm{w}}}$,

and $d_{\mathrm{c}}$ and $S_{\mathrm{c}}$ are the critical diameter and saturation ratio, respectively.

\section{Results and discussion}

\subsection{Observations of LLPS in $\alpha$-pinene-derived SOM particles: laboratory studies}

As the RH was scanned from high values $(\sim 100 \%)$ to low values $(\leq 0.5 \%)$ and, in reverse, LLPS in the SOM was clearly visible for $\mathrm{RH}>95 \%$. Example images are shown in Fig. 1. As the RH was increased from $<0.5 \%$ to $\sim 95 \%$, no change in the image was observed. The particles appear as a single phase. The light-colored circle in the center of the particle in panel a is an optical effect of light scattering from a hemispherical uniform particle (Bertram et al., 2011). Above $\sim 95 \% \mathrm{RH}$, the particle underwent spinodal decomposition, resulting in two phases (see Fig. 1 and movie S1 in the Supplement). Spinodal decomposition, a phenomenon by which the phase transition occurs with essentially no free energy barrier to nucleation of a second phase, is evident from the formation of the many small inclusions of the second 
Table 3. Calculated properties of the mixtures SOM-high, SOM-low and SOM-ox: average O : C elemental ratio, average molecular weight, simulated mass yields at 60\% RH reported in Zuend and Seinfeld (2012), range of LLPS for a $20 \mu \mathrm{m}$ particle in diameter, range of LLPS for a $100 \mathrm{~nm}$ particle in diameter, critical supersaturation SSc for a $100 \mathrm{~nm}$ particle with a surface tension of $72 \mathrm{mN} \mathrm{m}^{-1}$, critical supersaturation SSc for a $100 \mathrm{~nm}$ particle with a surface tension of $40 \mathrm{mN} \mathrm{m}^{-1}, \kappa_{\mathrm{HGF}}$ from the hygroscopic growth curve at $90 \% \mathrm{RH}$ for a $100 \mathrm{~nm}$ diameter particle and surface tension of $72 \mathrm{mN} \mathrm{m}^{-1}, \kappa_{\mathrm{HGF}}$ from the hygroscopic growth curve at $90 \% \mathrm{RH}$ for a 100 nm diameter particle and surface tension of $40 \mathrm{mN} \mathrm{m}^{-1}, \kappa_{\mathrm{CCN}}$ from SSc of the Köhler curve for a $100 \mathrm{~nm}$ particle and surface tension of $72 \mathrm{mN} \mathrm{m}^{-1}, \kappa_{\mathrm{CCN}}$ from SSc of the Köhler curve for a $100 \mathrm{~nm}$ particle and surface tension of $40 \mathrm{mN} \mathrm{m}^{-1}$.

\begin{tabular}{llll}
\hline & SOM-high & SOM-low & SOM-ox \\
\hline Av. O : & 0.472 & 0.513 & 0.582 \\
Av. $M_{\mathrm{W}}\left(\mathrm{g} \mathrm{mol}^{-1}\right)$ & 199.5 & 213.5 & 210.6 \\
PM mass conc. $\left(\mu \mathrm{g} \mathrm{m}^{-3}\right)$ & 21.86 & 0.81 & - \\
LLPS range $(\% \mathrm{RH}), 20 \mu \mathrm{m}$ & $99.31-99.88$ & $98.91-99.94$ & $98.71-99.92$ \\
LLPS range $(\% \mathrm{RH}), 100 \mathrm{~nm}$ & $>100 \%$ & $>100 \%$ & $>100 \%$ \\
SSc $(\%), 72 \mathrm{mN} \mathrm{m}^{-1}$ & 1.206 & 0.668 & 0.432 \\
SSc $(\%), 40 \mathrm{mN} \mathrm{m}^{-1}$ & 0.335 & 0.177 & 0.172 \\
$\kappa_{\mathrm{HGF}}$ at $90 \% \mathrm{RH}^{7} 72 \mathrm{mN} \mathrm{m}^{-1}$ & 0.0228 & 0.0278 & 0.0319 \\
$\kappa_{\mathrm{HGF}}$ at $90 \% \mathrm{RH}^{-1} 40 \mathrm{mN} \mathrm{m}^{-1}$ & 0.0228 & 0.0278 & 0.0319 \\
$\kappa_{\mathrm{CCN}}, 72 \mathrm{mN} \mathrm{m}^{-1}$ & 0.0093 & 0.0318 & 0.0758 \\
$\kappa_{\mathrm{CCN}}, 40 \mathrm{mN} \mathrm{m}^{-1}$ & 0.0198 & 0.0750 & 0.0793 \\
\hline
\end{tabular}

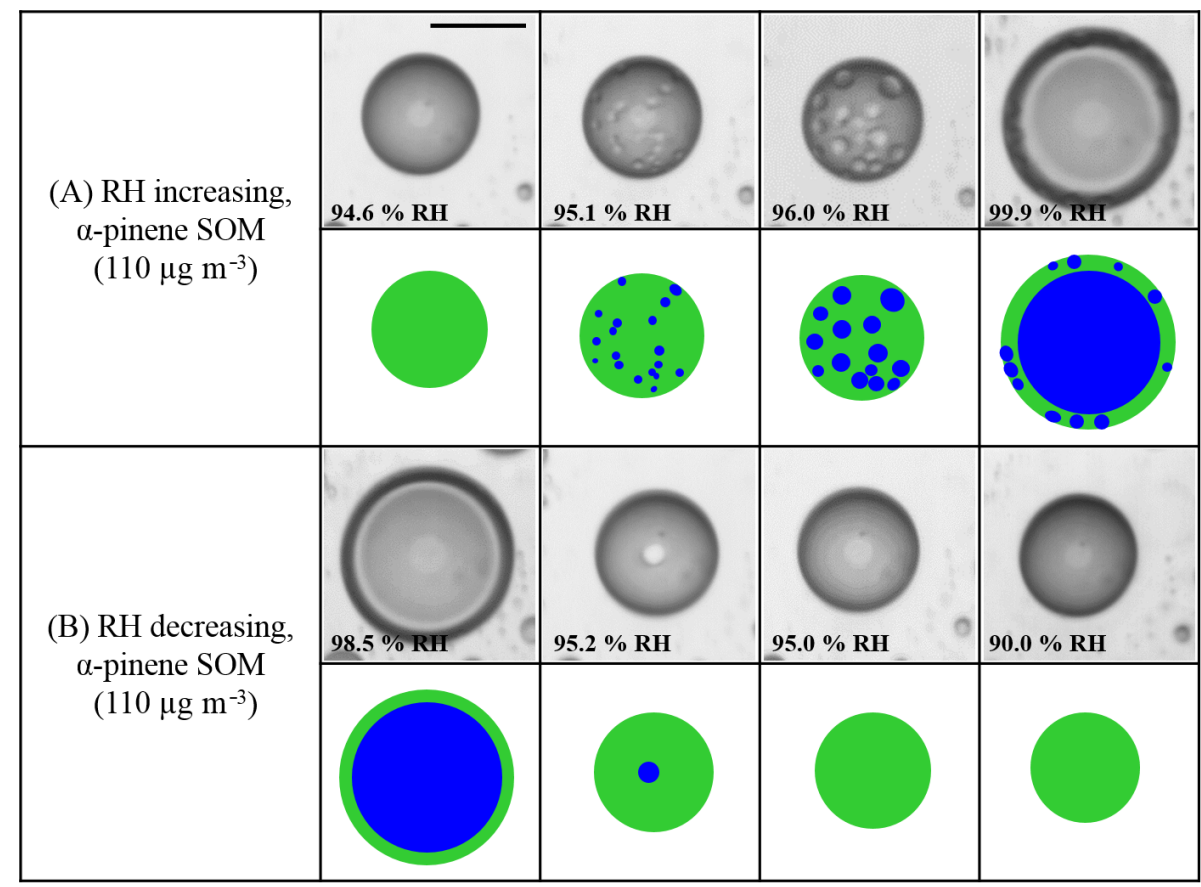

Figure 1. Effect of RH cycles on $\alpha$-pinene-derived SOM for SOM produced at $110 \mu \mathrm{g} \mathrm{m}^{-3}$. Illustrations of the images are shown for clarity. Green: SOM-rich phase. Blue: water-rich phase. Size bar is $20 \mu \mathrm{m}$.

phase throughout the particle (Ciobanu et al., 2009; Song et al., 2012). After phase separation by spinodal decomposition, the inclusions containing the second phase increased in size and coagulated into larger inclusions and eventually formed the inner phase of the particle as the RH was increased above $\sim 95 \%$ RH (see movie S1 in the Supplement). After phase separation, two liquid phases persisted until $\sim 100 \% \mathrm{RH}$.
Panel b of Fig. 1 and movie S2 in the Supplement show the same particle as panel a, but for experiments using decreasing $\mathrm{RH}$ starting from close to $100 \% \mathrm{RH}$. At $\sim 98 \%$ $\mathrm{RH}$, the particle contained two liquid phases. As the RH decreased from $\sim 98$ to $\sim 95 \%$, the thickness of the SOM-rich phase increased, while the amount of the water-rich phase decreased. Below $\sim 95 \% \mathrm{RH}$, the two phases merged into a single phase. As the RH was decreased further to $<0.5 \% \mathrm{RH}$, 


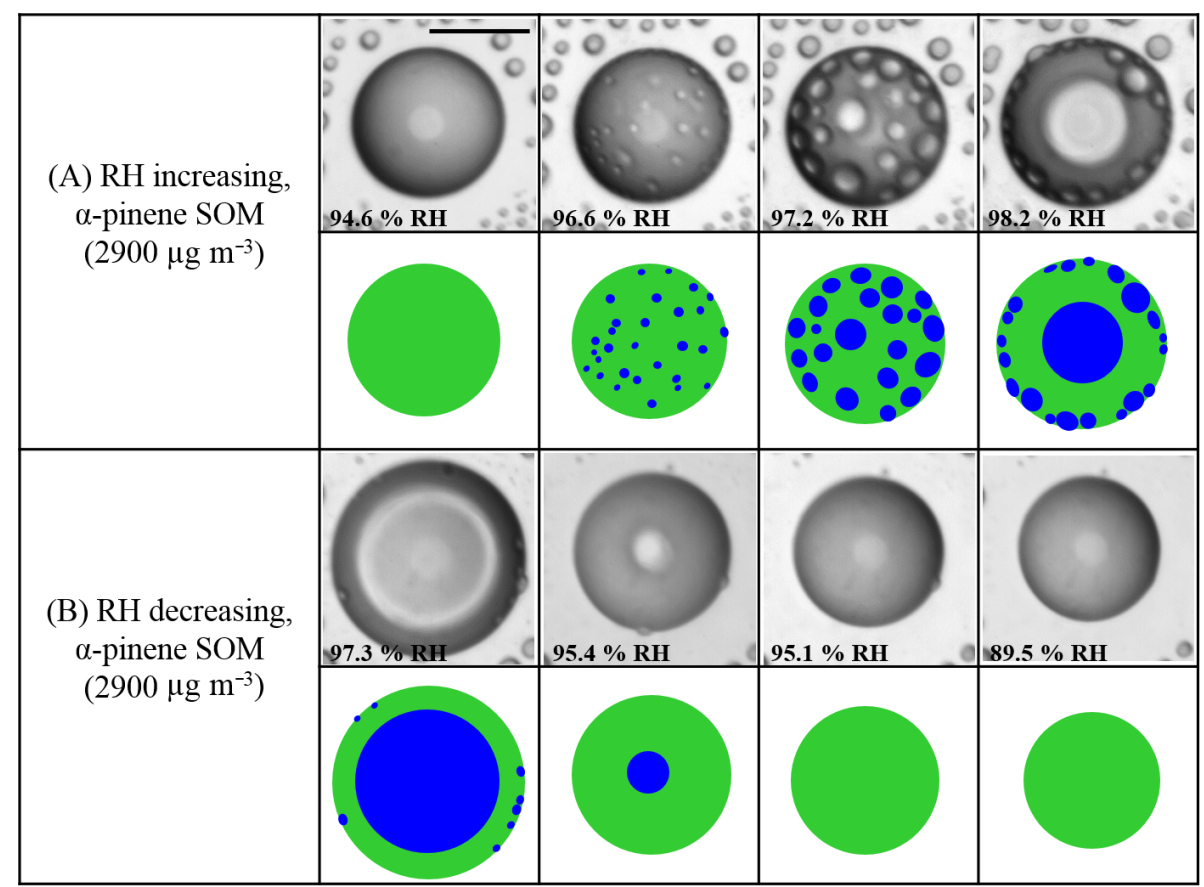

Figure 2. Effect of RH cycles on $\alpha$-pinene-derived SOM for SOM produced at $2900 \mu \mathrm{g} \mathrm{m}^{-3}$. Illustrations of the images are shown for clarity. Green: SOM-rich phase. Blue: water-rich phase. Size bar is $20 \mu \mathrm{m}$.

no abrupt change was observed, indicating the absence of any further phase transitions. Figure 2 and movies S3-S4 in the Supplement show similar pictures and movies as Fig. 1 and movies S1-S2 in the Supplement, except in this case the SOM was generated using a higher particle mass concentration in the flow tube reactor.

Figures 1-2 and movies S1-S4 in the Supplement show that there are differences in the process of LLPS and the resulting morphology depending on the direction of the RH change. For increasing RH, spinodal decomposition was identified as the mechanism of phase separation. For decreasing $\mathrm{RH}$, disappearance of phase separation occurred by merging of the two phases.

Experiments were also carried out to determine whether the lowest RH at which two phases existed depended on the direction of RH change. Values for the lowest RH at which two phases were observed when increasing and decreasing RH are listed in Table 1 and shown in Fig. 3 (black circles correspond to increasing RH and red circles correspond to decreasing RH). Table 1 and Fig. 3 illustrate that the lowest RH at which two phases were observed did not depend significantly on the direction of RH change. Figure 3 and Table 1 also show that within uncertainties of the measurements, there is no effect of the SOM particle mass concentrations in the flow tube reactor on the lowest RH at which two liquid phases were observed for the range of 75 to $11000 \mu \mathrm{g} \mathrm{m}^{-3}$. Also included in Fig. 3 are typical SOM particle mass concentrations measured over a boreal forest (Raatikainen et al., 2010), where $\alpha$-pinene is an important contributor to SOM (Cavalli et al., 2006). Since the SOM particle mass concentrations used in our experiments when generating the SOM were higher than typically observed in the atmosphere, additional studies are needed to confirm LLPS with SOM produced using atmospherically relevant particle mass concentrations.

The behavior observed here for SOM is consistent with bulk thermodynamics. Consider, for example, a mixture of a relatively hydrophobic organic with a less hydrophobic organic, such as a mixture containing equal mole ratios of heptanol and propanol (Stoicescu et al., 2011). Under dry conditions this mixture exists as a single phase. As water is added to the system, the mixture exists as a single (organic-rich) phase until the water content is approximately 0.3 mole fraction. At this point, the mixture separates into an organic-rich phase and a water-rich phase. As water is further added to the system, the two phases coexist until a large amount of water has been added, at which point all the organic material dissolves into the water-rich phase. The formation of two phases is due to the non-ideality of the mixture; i.e., if the mixture was ideal, LLPS would not be observed. Examples of other organic mixtures that exhibit this type of behavior include mixtures of hexanol and acetic acid (Senol et al., 2004) and mixtures of octanol and acetone (Tiryaki et al., 1994). For a long list of organic mixtures that undergo liquid-liquid phase separation when mixed with water, see Table 1 in Ganbavale et al. (2015). 


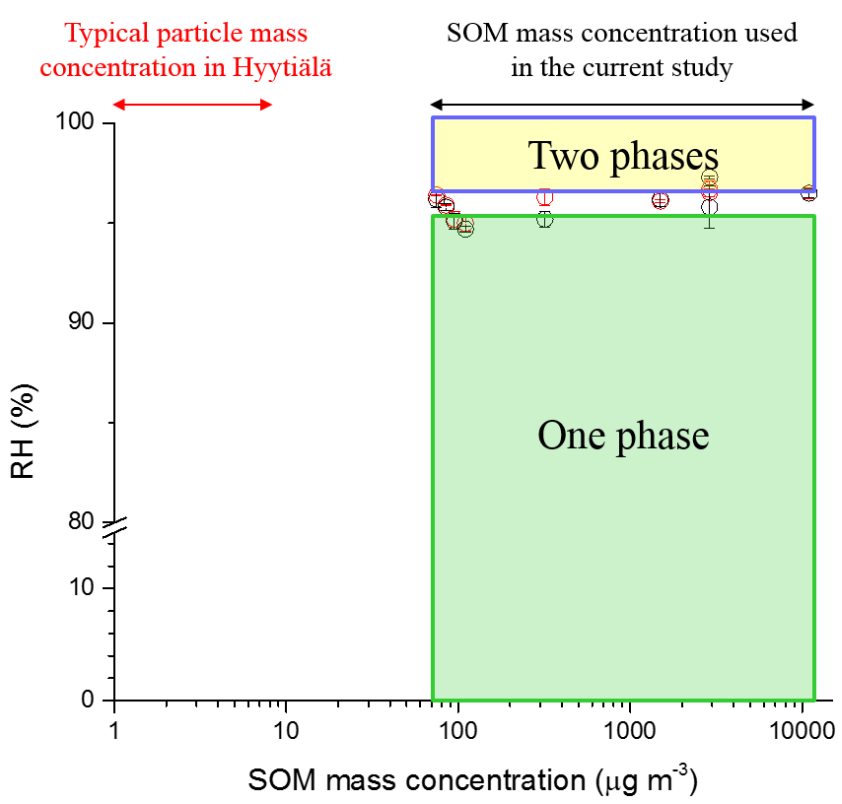

Figure 3. Relative humidity $(\mathrm{RH})$ at which phase transition between one phase and two liquid phases were observed for $\alpha$-pinenederived SOM as a function of the mass concentration of SOM produced. Red circles: onset of phase separation upon moistening. Black circles: merging of the two liquid phases upon drying. The $y$ error bars represent the standard deviation in RH determination at the phase transition. Green shaded region: one phase prevalent in $\alpha$-pinene-derived SOM. Yellow shaded region: two phases present. Also shown is the mass concentration observed over a representative boreal forest in Hyytiälä (Raatikainen et al., 2010).
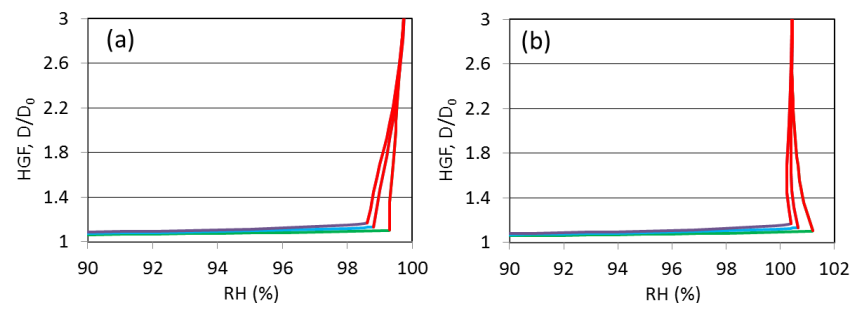

Figure 4. Simulated hygroscopic growth factors $\mathrm{HGF}=D / D_{0}$ for SOM-high (green, $\mathrm{O}: \mathrm{C}=0.472$ ), SOM-low (blue, $\mathrm{O}: \mathrm{C}=0.513$ ) and SOM-ox (purple, $\mathrm{O}: \mathrm{C}=0.582$ ). The red segments on the lines indicate the presence of LLPS. Panel (a) corresponds to a dry diameter of $20 \mu \mathrm{m}$, which is similar in size to the particles used in the optical microscope experiments, and a surface tension of water. Panel (b) corresponds to a dry diameter of $100 \mathrm{~nm}$ and a surface tension of water.

\subsection{Observations of LLPS in $\alpha$-pinene-derived SOM particles: thermodynamic modeling studies}

Shown in panel a of Fig. 4 are the simulated hygroscopic growth factors for the three different SOM mixtures (SOMhigh, SOM-low, SOM-ox) with a dry diameter of $20 \mu \mathrm{m}$, which is similar in size to the particles used in the optical
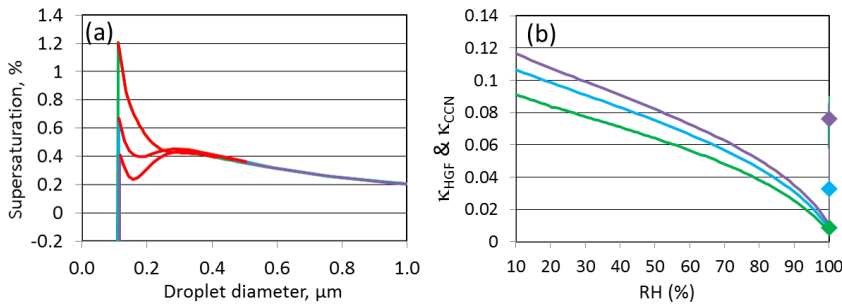

Figure 5. Assuming the surface tension of water, Köhler curves (panel a) and hygroscopicity parameter $\kappa$ (panel b) for a particle with a dry diameter of $100 \mathrm{~nm}$ for SOM-high (green, $\mathrm{O}: \mathrm{C}=0.472$ ), SOM-low (blue, $\mathrm{O}: \mathrm{C}=0.513$ ) and SOM-ox (purple, $\mathrm{O}: \mathrm{C}=0.582$ ). The red segments on the lines in panel (a) indicate the presence of LLPS. In panel (b), $\kappa_{\mathrm{HGF}}$ is given as solid line as a function of $\mathrm{RH}$ and $\kappa_{\mathrm{CCN}}$ as diamond at $\mathrm{RH}=100 \%$.

microscope experiments, and assuming a surface tension $(\sigma)$ of water. At RH values $<98 \%$ the SOM took up little water. However, when the multicomponent systems consisting of organic substances with different hydrophilicities (i.e., different $\mathrm{O}$ : C elemental ratios) were exposed to $\mathrm{RH}$ values $>98 \%$ $\mathrm{RH}$, LLPS into an organic-rich phase and a water-rich phase was observed. At the RH of LLPS, the particles took up a significant amount of water, leading to an almost vertical increase in the hygroscopic growth curve as shown in panel a of Fig. 4. For the SOM-high mixture LLPS occurred from 99.3 to $99.88 \% \mathrm{RH}$ as indicated by the red segment on the green line. When the share of the more hydrophilic substances is increased, as is the case for the low SOM loading (SOM-low) with a particle mass concentration of $0.81 \mu \mathrm{g} \mathrm{m}^{-3}$, the onset of LLPS shifted to lower RH and the RH range of LLPS was increased. In the laboratory experiments, LLPS was observed starting at $95 \% \mathrm{RH}$. This lower onset may be due to more highly oxidized products produced in the laboratory compared with the oxidation products used in the thermodynamic calculations. When the range of $\mathrm{O}: \mathrm{C}$ elemental ratios of the individual products used in the thermodynamic calculations is narrower than what is present in the SOM generated in the experiment, the calculated width of LLPS in terms of RH would be narrower than the measured one.

Shown in panel b of Fig. 4 are the simulated hygroscopic growth factors of a $100 \mathrm{~nm}$ dry particle for the three different SOM mixtures (SOM-high, SOM-low, SOM-ox), again assuming a surface tension of water. This figure illustrates that LLPS can shift to RH $>100 \%$ in small particles due to the Kelvin effect. In $100 \mathrm{~nm}$ particles, the SOM took up little water at $\mathrm{RH}<100 \%$, and LLPS is predicted above $100 \%$ $\mathrm{RH}$. 


\section{Implications}

\subsection{Cloud condensation nuclei properties}

The presence of a miscibility gap at RH $>95 \%$ has consequences for the $\mathrm{CCN}$ activity of particles as suggested previously (Petters et al., 2006). Shown in panel a of Fig. 5 are simulated Köhler curves for SOM particles with dry diameters of $100 \mathrm{~nm}$ and using the surface tension of water. The Köhler curves show a sharp increase in the equilibrium water vapor SS above the particles as the size of the particles increases from 100 to roughly $110 \mathrm{~nm}$ due to the Kelvin effect when they are still in their organic-rich phase (i.e., low water content state). As the particle size increases from 110 to $200 \mathrm{~nm}$ there is a steep decrease in SS as the particles switch from the organic-rich phase to two phases by taking up water from the gas phase. This gives rise to the first maximum in the Köhler curve, which occurs at a wet particle diameter of $D_{\mathrm{p}} \approx 110 \mathrm{~nm}$ for the SOM-high mixture. The second maximum of SS at a wet diameter of $D_{\mathrm{p}} \approx 300 \mathrm{~nm}$ is the regular maximum of the Köhler curve, which occurs when the droplet is dilute and close to solution ideality. When the particle is composed of higher shares of the more hydrophilic substances, the first maximum decreases in height while the second maximum remains constant (see panel a of Fig. 5). For SOM-high $(\mathrm{O}: \mathrm{C}=0.472)$ and SOMlow $(\mathrm{O}: \mathrm{C}=0.513)$, the first maximum in the Köhler curve determines the critical SS to overcome the activation barrier. In $\mathrm{SOM}-\mathrm{ox}(\mathrm{O}: \mathrm{C}=0.582)$ the second maximum is higher than the first one and relevant for $\mathrm{CCN}$ activation. The height of the second maximum in the Köhler curve is sensitive to the molecular weight of the organic substances making up the particle (e.g., Wex et al., 2007, 2008).

Shown in panel a of Fig. 6 are simulated Köhler curves for SOM particles with dry diameters of $100 \mathrm{~nm}$ and using the surface tension of $40 \mathrm{mN} \mathrm{m}^{-1}$, which is consistent with the surface tension of aqueous mixtures of pinonic acid, pinic acid and pinonaldehyde (Tuckermann and Cammenga, 2004; Hartz et al., 2006). Panel a of Fig. 6 illustrates that a lower surface tension has a large effect on the first maximum in the Köhler curve and also lowers the barrier of the second maximum. During the activation process, the surface tension is expected to increase as the phase state changes from organic rich to water rich, but this process is not modeled here. Additional studies are needed to fully understand the effect of varying surface tension on the resulting Köhler curves (Ruehl et al., 2016).

The non-ideality of SOM also has consequences for the applicability of the single parameter $\kappa$ representation of Köhler theory (Petters and Kreidenweis, 2007). If SOM forms an ideal mixture with water then $\kappa_{\mathrm{HGF}}$ is approximately constant over the whole $\mathrm{RH}$ range and $\kappa_{\mathrm{CCN}}$ corresponds well with $\kappa_{\mathrm{HGF}}$ for an organic particle (Petters and Kreidenweis, 2007). However, panel b of Figs. 5 and 6 show that $\kappa_{\mathrm{HGF}}$ for the mixtures SOM-high, SOM-low and SOM-ox with a
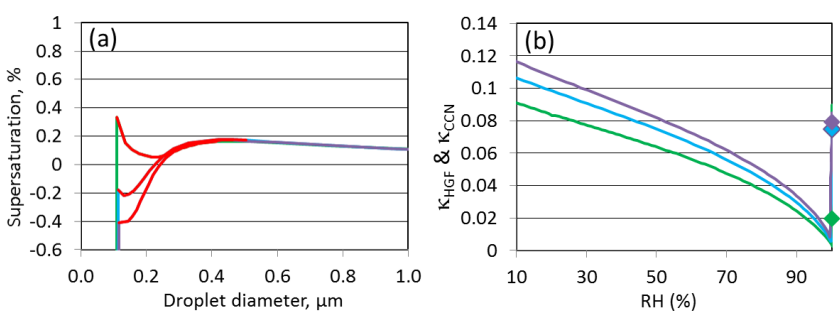

Figure 6. Assuming a surface tension of $40 \mathrm{mN} \mathrm{m}^{-1}$, Köhler curves (panel a) and hygroscopicity parameter $\kappa$ (panel b) for a particle with a dry diameter of $100 \mathrm{~nm}$ for SOM-high (green, $\mathrm{O}: \mathrm{C}=0.472$ ), SOM-low (blue, $\mathrm{O}: \mathrm{C}=0.513$ ) and SOM-ox (purple, $\mathrm{O}: \mathrm{C}=0.582$ ). The red segments on the lines in panel (a) indicate the presence of LLPS. In panel (b), $\kappa_{\mathrm{HGF}}$ is given as solid line as a function of $\mathrm{RH}$ and $\kappa_{\mathrm{CCN}}$ as diamond at $\mathrm{RH}=100 \%$.

dry diameter of $100 \mathrm{~nm}$ are not constant over the whole RH range. Due to the solution non-ideality, $\kappa_{\mathrm{HGF}}$ decreases as the $\mathrm{RH}$ increases. In addition, $\kappa_{\mathrm{CCN}}$ strongly depends on whether the first or the second maximum in the Köhler curve is limiting $\mathrm{CCN}$ activation.

Recently researchers have observed inconsistencies between measured CCN properties of SOM particles and hygroscopic growth measured below water saturation. In other words, hygroscopic parameters measured below water saturation were inconsistent with hygroscopic parameters measured above water saturation. Several reasons have been put forward to explain these discrepancies (Petters et al., 2006, 2009; Prenni et al., 2007; Juranyi et al., 2009; Good et al., 2010; Massoli et al., 2010; Hersey et al., 2013; Pajunoja et al., 2015). The results shown in panel b of Figs. 5-6 illustrate that such inconsistencies are expected for systems with LLPS when the water uptake at subsaturated conditions represents the hygroscopicity of the organic-rich phase while the barrier for CCN activation is determined by the second maximum in the Köhler curve when the particles are water rich. Additional laboratory studies are needed to determine whether LLPS occurs in $\alpha$-pinene SOM generated with particle mass concentrations typically found in the atmosphere. Additional studies are also needed to determine if LLPS occurs in other types of SOM particles of atmospheric relevance.

\section{The Supplement related to this article is available online at doi:10.5194/acp-16-7969-2016-supplement.}

Acknowledgements. This work was supported by the Natural Sciences and Engineering Research Council of Canada. Support from the US National Science Foundation and the US Department of Energy is also acknowledged. Claudia Marcolli acknowledges the Competence Center Environment and Sustainability of the ETH Domain (CCES) project OPTIWARES for financial support and Andreas Zuend for providing the program to perform the model 
calculations. The authors would also like to thank Doug Worsnop for enthusiastic and motivating discussions related to the current manuscript.

Edited by: A. Virtanen

\section{References}

Bertram, A. K., Martin, S. T., Hanna, S. J., Smith, M. L., Bodsworth, A., Chen, Q., Kuwata, M., Liu, A., You, Y., and Zorn, S. R.: Predicting the relative humidities of liquid-liquid phase separation, efflorescence, and deliquescence of mixed particles of ammonium sulfate, organic material, and water using the organic-to-sulfate mass ratio of the particle and the oxygen-tocarbon elemental ratio of the organic component, Atmos. Chem. Phys., 11, 10995-11006, doi:10.5194/acp-11-10995-2011, 2011.

Bilde, M. and Svenningsson, B.: CCN activation of slightly soluble organics: the importance of small amounts of inorganic salt and particle phase, Tellus B, 56, 128-134, doi:10.1111/j.16000889.2004.00090.x, 2004.

Cavalli, F., Facchini, M. C., Decesari, S., Emblico, L., Mircea, M., Jensen, N. R., and Fuzzi, S.: Size-segregated aerosol chemical composition at a boreal site in southern Finland, during the QUEST project, Atmos. Chem. Phys., 6, 993-1002, doi:10.5194/acp-6-993-2006, 2006.

Chhabra, P. S., Ng, N. L., Canagaratna, M. R., Corrigan, A. L., Russell, L. M., Worsnop, D. R., Flagan, R. C., and Seinfeld, J. H.: Elemental composition and oxidation of chamber organic aerosol, Atmos. Chem. Phys., 11, 8827-8845, doi:10.5194/acp-11-88272011, 2011.

Ciobanu, V. G., Marcolli, C., Krieger, U. K., Weers, U., and Peter, T.: Liquid-liquid phase separation in Mixed Organic/Inorganic Aerosol Particles, J. Phys. Chem. A, 113, 10966-10978, doi:10.1021/Jp905054d, 2009.

Compernolle, S., Ceulemans, K., and Müller, J.-F.: EVAPORATION: a new vapour pressure estimation methodfor organic molecules including non-additivity and intramolecular interactions, Atmos. Chem. Phys., 11, 9431-9450, doi:10.5194/acp-119431-2011, 2011.

Ganbavale, G., Zuend, A., Marcolli, C., and Peter, T.: Improved AIOMFAC model parameterisation of the temperature dependence of activity coefficients for aqueous organic mixtures, Atmos. Chem. Phys., 15, 447-493, doi:10.5194/acp-15-447-2015, 2015.

Good, N., Topping, D. O., Duplissy, J., Gysel, M., Meyer, N. K., Metzger, A., Turner, S. F., Baltensperger, U., Ristovski, Z., Weingartner, E., Coe, H., and McFiggans, G.: Widening the gap between measurement and modelling of secondary organic aerosol properties?, Atmos. Chem. Phys., 10, 2577-2593, doi:10.5194/acp-10-2577-2010, 2010.

Grayson, J. W., Zhang, Y., Mutzel, A., Renbaum-Wolff, L., Böge, O., Kamal, S., Herrmann, H., Martin, S. T., and Bertram, A. K.: Effect of varying experimental conditions on the viscosity of $\alpha$ pinene derived secondary organic material, Atmos. Chem. Phys., 16, 6027-6040, doi:10.5194/acp-16-6027-2016, 2016.

Hallquist, M., Wenger, J. C., Baltensperger, U., Rudich, Y., Simpson, D., Claeys, M., Dommen, J., Donahue, N. M., George, C., Goldstein, A. H., Hamilton, J. F., Herrmann, H., Hoffmann, T.,
Iinuma, Y., Jang, M., Jenkin, M. E., Jimenez, J. L., KiendlerScharr, A., Maenhaut, W., McFiggans, G., Mentel, T. F., Monod, A., Prevot, A. S. H., Seinfeld, J. H., Surratt, J. D., Szmigielski, R., and Wildt, J.: The formation, properties and impact of secondary organic aerosol: current and emerging issues, Atmos. Chem. Phys., 9, 5155-5236, doi:10.5194/acp-9-5155-2009, 2009.

Hartz, K. E. H., Tischuk, J. E., Chan, M. N., Chan, C. K., Donahue, N. M., and Pandis, S. N.: Cloud condensation nuclei activation of limited solubility organic aerosol, Atmos. Environ., 40, 605-617, doi:10.1016/j.atmosenv.2005.09.076, 2006.

Hersey, S. P., Craven, J. S., Metcalf, A. R., Lin, J., Lathem, T., Suski, K. J., Cahill, J. F., Duong, H. T., Sorooshian, A., Jonsson, H. H., Shiraiwa, M., Zuend, A., Nenes, A., Prather, K. A., Flagan, R. C., and Seinfeld, J. H.: Composition and hygroscopicity of the Los Angeles Aerosol: CalNex, J. Geophys. Res.-Atmos., 118, 30163036, doi:10.1002/jgrd.50307, 2013.

Jenkin, M. E., Saunders, S. M., and Pilling, M. J.: The tropospheric degradation of volatile organic compounds: A protocol for mechanism development, Atmos. Environ., 31, 81-104, doi:10.1016/S1352-2310(96)00105-7, 1997.

Jimenez, J. L., Canagaratna, M. R., Donahue, N. M., Prevot, A. S. H., Zhang, Q., Kroll, J. H., DeCarlo, P. F., Allan, J. D., Coe, H., Ng, N. L., Aiken, A. C., Docherty, K. S., Ulbrich, I. M., Grieshop, A. P., Robinson, A. L., Duplissy, J., Smith, J. D., Wilson, K. R., Lanz, V. A., Hueglin, C., Sun, Y. L., Tian, J., Laaksonen, A., Raatikainen, T., Rautiainen, J., Vaattovaara, P., Ehn, M., Kulmala, M., Tomlinson, J. M., Collins, D. R., Cubison, M. J., Dunlea, E. J., Huffman, J. A., Onasch, T. B., Alfarra, M. R., Williams, P. I., Bower, K., Kondo, Y., Schneider, J., Drewnick, F., Borrmann, S., Weimer, S., Demerjian, K., Salcedo, D., Cottrell, L., Griffin, R., Takami, A., Miyoshi, T., Hatakeyama, S., Shimono, A., Sun, J. Y., Zhang, Y. M., Dzepina, K., Kimmel, J. R., Sueper, D., Jayne, J. T., Herndon, S. C., Trimborn, A. M., Williams, L. R., Wood, E. C., Middlebrook, A. M., Kolb, C. E., Baltensperger, U., and Worsnop, D. R.: Evolution of organic aerosols in the atmosphere, Science, 326, 1525-1529, doi:10.1126/science.1180353, 2009.

Juranyi, Z., Gysel, M., Duplissy, J., Weingartner, E., Tritscher, T., Dommen, J., Henning, S., Ziese, M., Kiselev, A., Stratmann, F., George, I., and Baltensperger, U.: Influence of gas-to-particle partitioning on the hygroscopic and droplet activation behaviour of alpha-pinene secondary organic aerosol, Phys. Chem. Chem. Phys., 11, 8091-8097, doi:10.1039/B904162a, 2009.

Knopf, D. A.: Thermodynamic properties and nucleation processes of upper tropospheric and lower stratospheric aerosol particles, Diss. ETH No. 15103, Zurich, Switzerland, 2003.

Koop, T., Kapilashrami, A., Molina, L. T., and Molina, M. J.: Phase transitions of sea-salt/water mixtures at low temperatures: Implications for ozone chemistry in the polar marine boundary layer, J. Geophys. Res.-Atmos., 105, 26393-26402, doi:10.1029/2000jd900413, 2000.

Krieger, U. K., Marcolli, C., and Reid, J. P.: Exploring the complexity of aerosol particle properties and processes using single particle techniques, Chem. Soc. Rev., 41, 6631-6662, doi:10.1039/c2cs35082c, 2012.

Kuwata, M. and Martin, S. T.: Phase of atmospheric secondary organic material affects its reactivity, P. Natl. Acad. Sci. USA, 109, 17354-17359, doi:10.1073/pnas.1209071109, 2012. 
Liu, P. F., Zhang, Y., and Martin, S. T.: Complex refractive indices of thin films of secondary organic materials by spectroscopic ellipsometry from 220 to $1200 \mathrm{~nm}$, Environ. Sci. Technol., 47, 13594-13601, doi:10.1021/Es403411e, 2013.

Martin, S. T.: Phase transitions of aqueous atmospheric particles, Chem. Rev., 100, 3403-3453, doi:10.1021/Cr990034t, 2000.

Massoli, P., Lambe, A. T., Ahern, A. T., Williams, L. R., Ehn, M., Mikkila, J., Canagaratna, M. R., Brune, W. H., Onasch, T. B., Jayne, J. T., Petaja, T., Kulmala, M., Laaksonen, A., Kolb, C. E., Davidovits, P., and Worsnop, D. R.: Relationship between aerosol oxidation level and hygroscopic properties of laboratory generated secondary organic aerosol (SOM) particles, Geophys. Res. Lett., 37, L24801, doi:10.1029/2010g1045258, 2010.

Pajunoja, A., Lambe, A. T., Hakala, J., Rastak, N., Cummings, M. J., Brogan, J. F., Hao, L. Q., Paramonov, M., Hong, J., Prisle, N. L., Malila, J., Romakkaniemi, S., Lehtinen, K. E. J., Laaksonen, A., Kulmala, M., Massoli, P., Onasch, T. B., Donahue, N. M., Riipinen, I., Davidovits, P., Worsnop, D. R., Petaja, T., and Virtanen, A.: Adsorptive uptake of water by semisolid secondary organic aerosols, Geophys. Res. Lett., 42, 3063-3068, doi:10.1002/2015g1063142, 2015.

Pankow, J. F.: Gas/particle partitioning of neutral and ionizing compounds to single and multi-phase aerosol particles. 1. Unified modeling framework, Atmos. Environ., 37, 3323-3333, doi:10.1016/S1352-2310(03)00346-7, 2003.

Pant, A., Parsons, M. T., and Bertram, A. K.: Crystallization of aqueous ammonium sulfate particles internally mixed with soot and kaolinite: Crystallization relative humidities and nucleation rates, J. Phys. Chem. A, 110, 8701-8709, doi:10.1021/Jp060985s, 2006.

Parsons, M. T., Knopf, D. A., and Bertram, A. K.: Deliquescence and crystallization of ammonium sulfate particles internally mixed with water-soluble organic compounds, J. Phys. Chem. A, 108, 11600-11608, doi:10.1021/Jp0462862, 2004.

Petters, M. D. and Kreidenweis, S. M.: A single parameter representation of hygroscopic growth and cloud condensation nucleus activity, Atmos. Chem. Phys., 7, 1961-1971, doi:10.5194/acp-71961-2007, 2007.

Petters, M. D., Kreidenweis, S. M., Snider, J. R., Koehler, K. A., Wang, Q., Prenni, A. J., and Demott, P. J.: Cloud droplet activation of polymerized organic aerosol, Tellus B, 58, 196-205, doi:10.1111/j.1600-0889.2006.00181.x, 2006.

Petters, M. D., Wex, H., Carrico, C. M., Hallbauer, E., Massling, A., McMeeking, G. R., Poulain, L., Wu, Z., Kreidenweis, S. M., and Stratmann, F.: Towards closing the gap between hygroscopic growth and activation for secondary organic aerosol - Part 2: Theoretical approaches, Atmos. Chem. Phys., 9, 3999-4009, doi:10.5194/acp-9-3999-2009, 2009.

Pöschl, U., Martin, S. T., Sinha, B., Chen, Q., Gunthe, S. S., Huffman, J. A., Borrmann, S., Farmer, D. K., Garland, R. M., Helas, G., Jimenez, J. L., King, S. M., Manzi, A., Mikhailov, E., Pauliquevis, T., Petters, M. D., Prenni, A. J., Roldin, P., Rose, D., Schneider, J., Su, H., Zorn, S. R., Artaxo, P., and Andreae, M. O.: Rainforest aerosols as biogenic nuclei of clouds and precipitation in the Amazon, Science, 329, 1513-1516, doi:10.1126/science.1191056, 2010.

Prenni, A. J., Petters, M. D., Kreidenweis, S. M., DeMott, P. J., and Ziemann, P. J.: Cloud droplet activation of sec- ondary organic aerosol, J. Geophys. Res.-Atmos., 112, D10223, doi:10.1029/2006jd007963, 2007.

Prenni, A. J., Petters, M. D., Kreidenweis, S. M., Heald, C. L., Martin, S. T., Artaxo, P., Garland, R. M., Wollny, A. G., and Poschl, U.: Relative roles of biogenic emissions and Saharan dust as ice nuclei in the Amazon basin, Nat. Geosci., 2, 401-404, doi:10.1038/Ngeo517, 2009.

Raatikainen, T., Vaattovaara, P., Tiitta, P., Miettinen, P., Rautiainen, J., Ehn, M., Kulmala, M., Laaksonen, A., and Worsnop, D. R.: Physicochemical properties and origin of organic groups detected in boreal forest using an aerosol mass spectrometer, Atmos. Chem. Phys., 10, 2063-2077, doi:10.5194/acp-10-20632010, 2010.

Raymond, T. M. and Pandis, S. N.: Cloud activation of singlecomponent organic aerosol particles, J. Geophys. Res.-Atmos., 107, 4787, doi:10.1029/2002jd002159, 2002.

Ruehl, C. R., Davies, J. F., and Wilson, K. R.: An interfacial mechanism for cloud droplet formation on organic aerosols, Science, 351, 1447-1450, doi:10.1126/science.aad4889, 2016.

Saunders, S. M., Jenkin, M. E., Derwent, R. G., and Pilling, M. J.: Protocol for the development of the Master Chemical Mechanism, MCM v3 (Part A): tropospheric degradation of nonaromatic volatile organic compounds, Atmos. Chem. Phys., 3, 161-180, doi:10.5194/acp-3-161-2003, 2003.

Senol, A.: Phase equilibria for ternary liquid systems of (water plus carboxylic acid or alcohol plus 1-hexanol) at $T=293.15 \mathrm{~K}$ : modelling considerations, J. Chem. Thermodyn., 36, 1007-1014, doi:10.1016/j.jct.2004.07.016, 2004.

Shrestha, M., Zhang, Y., Ebben, C. J., Martin, S. T., and Geiger, F. M.: Vibrational sum frequency generation spectroscopy of secondary organic material produced by condensational growth from alpha-pinene ozonolysis, J. Phys. Chem. A, 117, 84278436, doi:10.1021/Jp405065d, 2013.

Song, M., Marcolli, C., Krieger, U. K., Zuend, A., and Peter, T.: Liquid-liquid phase separation and morphology of internally mixed dicarboxylic acids/ammonium sulfate/water particles, Atmos. Chem. Phys., 12, 2691-2712, doi:10.5194/acp-12-26912012, 2012.

Song, M., Liu, P. F., Hanna, S. J., Li, Y. J., Martin, S. T., and Bertram, A. K.: Relative humidity-dependent viscosities of isoprene-derived secondary organic material and atmospheric implications for isoprene-dominant forests, Atmos. Chem. Phys., 15, 5145-5159, doi:10.5194/acp-15-5145-2015, 2015.

Stoicescu, C., Iulian, O., and Isopescu, R.: Liquid-Liquid phase equilibria of (1-propanol + water $+n$-alcohol) ternary systems at 294.15 K. II. 1-propanol + water+1-heptanol or 1-octanol or 1-nonanol or 1-decanol, Rev. Roum. Chim., 56, 553-560, 2011.

Tiryaki, A., Guruz, G., and Orbey, H.: Liquid-Liquid Equilibria of Ternary-Systems of Water Plus Acetone and C-5-Alcohol and C8-Alcohol at 298-K, 303-K and 308-K, Fluid. Phase. Equilibr., 94, 267-280, doi:10.1016/0378-3812(94)87061-6, 1994.

Tuckermann, R. and Cammenga, H. K.: The surface tension of aqueous solutions of some atmospheric watersoluble organic compounds, Atmos Environ, 38, 6135-6138, doi:10.1016/j.atmosenv.2004.08.005, 2004.

Wex, H., Hennig, T., Salma, I., Ocskay, R., Kiselev, A., Henning, S., Massling, A., Wiedensohler, A., and Stratmann, F.: Hygroscopic growth and measured and modeled critical super-saturations of 
an atmospheric HULIS sample, Geophys. Res. Lett., 34, L02818, doi:10.1029/2006GL028260, 2007.

Wex, H., Topping, D., McFiggans, G., and Stratmann, F.: The Kelvin versus the Raoult term in the Köhler equation, J. Atmos. Sci., 65, 4004-4016, doi:10.1175/2008JAS2720.1, 2008.

You, Y., Smith, M. L., Song, M. J., Martin, S. T., and Bertram, A. K.: Liquid-liquid phase separation in atmospherically relevant particles consisting of organic species and inorganic salts, Int. Rev. Phys. Chem., 33, 43-77, doi:10.1080/0144235X.2014.890786, 2014.

Zhang, Q., Jimenez, J. L., Canagaratna, M. R., Allan, J. D., Coe, H., Ulbrich, I., Alfarra, M. R., Takami, A., Middlebrook, A. M., Sun, Y. L., Dzepina, K., Dunlea, E., Docherty, K., DeCarlo, P. F., Salcedo, D., Onasch, T., Jayne, J. T., Miyoshi, T., Shimono, A., Hatakeyama, S., Takegawa, N., Kondo, Y., Schneider, J., Drewnick, F., Borrmann, S., Weimer, S., Demerjian, K., Williams, P., Bower, K., Bahreini, R., Cottrell, L., Griffin, R. J., Rautiainen, J., Sun, J. Y., Zhang, Y. M., and Worsnop, D. R.: Ubiquity and dominance of oxygenated species in organic aerosols in anthropogenically-influenced Northern Hemisphere midlatitudes, Geophys. Res. Lett., 34, L13801, doi:10.1029/2007g1029979, 2007.

Zuend, A. and Seinfeld, J. H.: Modeling the gas-particle partitioning of secondary organic aerosol: the importance of liquidliquid phase separation, Atmos. Chem. Phys., 12, 3857-3882, doi:10.5194/acp-12-3857-2012, 2012.
Zuend, A. and Seinfeld, J. H.: A practical method for the calculation of liquid-liquid equilibria in multicomponent organicwater-electrolyte systems using physicochemical constraints, Fluid Phase Equilibr., 337, 201-213, 2013.

Zuend, A., Marcolli, C., Luo, B. P., and Peter, T.: A thermodynamic model of mixed organic-inorganic aerosols to predict activity coefficients, Atmos. Chem. Phys., 8, 4559-4593, doi:10.5194/acp8-4559-2008, 2008.

Zuend, A., Marcolli, C., Peter, T., and Seinfeld, J. H.: Computation of liquid-liquid equilibria and phase stabilities: implications for RH-dependent gas/particle partitioning of organic-inorganic aerosols, Atmos. Chem. Phys., 10, 7795-7820, doi:10.5194/acp10-7795-2010, 2010.

Zuend, A., Marcolli, C., Booth, A. M., Lienhard, D. M., Soonsin, V., Krieger, U. K., Topping, D. O., McFiggans, G., Peter, T., and Seinfeld, J. H.: New and extended parameterization of the thermodynamic model AIOMFAC: calculation of activity coefficients for organic-inorganic mixtures containing carboxyl, hydroxyl, carbonyl, ether, ester, alkenyl, alkyl, and aromatic functional groups, Atmos. Chem. Phys., 11, 9155-9206, doi:10.5194/acp11-9155-2011, 2011. 